\title{
Spatial Dimensions of Urban Growth and Land Use Changes in a Small City of Bahawalpur District, Pakistan
}

\author{
Sana Arshad*, Mahwish Nawaz Malik, Majid Malik
}

Department of Geography, the Islamia University Bahawalpur, Pakistan

Copyright $@ 2017$ by authors, all rights reserved. Authors agree that this article remains permanently open access under the terms of the Creative Commons Attribution License 4.0 International License

\begin{abstract}
Studying the relationship between urban growth and land use changes is of considerable importance. Urban growth of small and big cities is largely dependent upon conversion and transformation of land use. Determining the impacts of land use changes on urban growth is also affected by population growth and distribution. The current research is also focused on the analyzing the process of urban growth of a small city present on the western side of Bahawalpur district named "Uch Sharif". Before 1980, it was included in one of the urbanizing town of the Pakistan which gained the status of small city due to increased urban population and land use development after 1981. The major objective of the current research is to analyze the spatial and temporal dimensions of urban and population growth of the city from 1973 to 2016. Study is based on land use maps of the city prepared in GIS environment to determine the residential and urban growth of the city. At the end rate of urban expansion and population growth rate concludes the urban expansion of the city is taking place in different directions verifying urbanization of this small city. Such studies are very useful to get appropriate knowledge of land use growth and its associated factors for future urban planning.
\end{abstract}

Keywords Urban Growth Rate, Population Growth Rate, Land Use Change

\section{Introduction}

Land is the biggest resource to perform various kind of human activities but its use varies according to functions and activities performed hereby like food production, material processing and so on [1]. Variations exist between the similar terms land cover and land use. Moser [2] defined the term land cover as "the type of vegetation that cover the earth surfaces and ground water" while Meyer and Turner [3] stated that "land use is the way in which and the purpose for which human beings employ the land and its resources. Mitra and Sharma [4] also stated land use as "A series of operations on land carried by humans with the intention of obtaining products and benefits. Briassoulis [5] differentiated between land cover as physical, ecological and biological categorization of the terrestrial earth's surface while land use as human purposes that are associated with it.

The surface of the earth has been altered considerably over the past 50 years by human activities like urbanization, deforestation, and intensive agriculture which resulted an unbalance in ecosystem services and also shaped the structure of cities [6] Modifications and alterations due to such human activities on the terrestrial surface have generated the concept of urban growth and land use change also causing very serious impacts on environment and biodiversity. [7] Expansion of urban areas are playing significant role in modifying the use of land. United Nations [8] describes urban growth as increase of urban population of any town or city which can be due to natural increase, rural urban migration or reclassification of rural settlements into towns or cities. It is most important social transformation in the history of human civilization. Population growth is one of the significant phenomenons which cause urban growth and expansion of cities in any direction. Other than population, economic and technological development can also cause rapid urban growth in the form of suburban expansion and also many changes in the city center [9]. In another study by Rui [10] also stated that urbanization and rapid population growth have triggered an increased demand of land for urban settlements. But growth of cities is not only limited to population increase but it also changes in spatial dimensions. Hence population growth is not only a single factor but increasing urban requirements such as the need of transportation facilities, educational and other public facilities also contributes for changes in land use pattern and urban growth [11].

Although urbanization is occurring in all less developed countries but Asia accounts for its highest contribution. Starting from 1950, urban population of Asia was $17 \%$ of total which reached to $40 \%$ in 2005 and estimated to reach 55\% by the year 2030. [12]. Pakistan is included in top ten countries of the world by population and is considered as fastest growing country in the context of urbanization and is considered as most urbanized country of South Asia. Its 
urban population has been increased three times since last three decades and has been reached from 32\% in 1998 to $40 \%$ in 2014 and expected to reach 50\% by 2025[13].

It is a common observation that cities grow with time but the rate of expansion is not always uniform over several decades and depends upon numerous associated factors. Expansion of cities requires more and more land which ultimately put pressure on suburban rural land and alters the land use pattern of particular area. To get accurate information about extent of city growth it is very necessary to properly map the urban limits and also use some indicators to measure the rate of expansion $[14,15]$ e.g Xia [16] used annual urban growth rate to evaluate the urban expansion of Shijiazhuang city in North China. Similarly Aljoufie [14] also indicated annual urban spatial index, land use change index and population density index as an effective indicator to measure the relationship between urban growth and transportation.

Keeping in view the issue of urban expansion in small

1. To analyze the spatial dimensions of urban growth by measuring the change in land use pattern of the city between 1973 to 2016

2. To examine the population growth of the city with respect to urban growth years

3. To evaluate the annual rate of urban growth using spatial indicators of urban expansion and population growth

\section{Material and Method}

Area selected for the current research is a small city located on the Western side in District Bahawalpur of
Pakistan represented in figure 1. There are five major tehsil of district Bahawalpur named Tehsil Bahawalpur, Tehsil Yazman, Tehsil Khairpur Tamewali, Tehsil Hasilpur and Tehsil Ahmadpur East. This small historical city is located on the northern side of tehsil Ahmadpur East and has its significant historical importance due to ancient mausoleum, shrines, tombs and ancient graveyards [17]. The city comprises traditional settlement fabric on historic mound having a linear spin bazaar (Chunri Bazaar), in addition to recent growth of residential quarters. City is divided in two historic quarters which are Uch Bukhari and Uch Gillani. Uch Bukhari is the oldest part of the city named after Hazrat Syed JalaludDin Bukhari, a great sufi Saint of $13^{\text {th }}$ century. The second famous quarter in "Uch Gillani" named after Hazrat Jillani. It is the recent and larger quarter of the city. The Descendants of famous saints are the keepers of their shrines and earned revenue from the shrine's income. Furthermore, they also brought a large portion of land under cultivation from periphery areas of the city for subsistence needs [18]. The physical structure and settlement pattern of the city still reflected the processes of growth and development associated with the expansion of these clans of Sufis, and the religious centrality they brought to Uch Sharif. The historical significance of Uch Sharif and its geographical importance as a riverain area made it an important place for people to reside and migrate from other areas. Increasing population pressure and agricultural development altered the land use of city since last 40 years and made it a significant place of economic development.

To achieve the research objectives, data for the study is collected from various sources mentioned in table1.

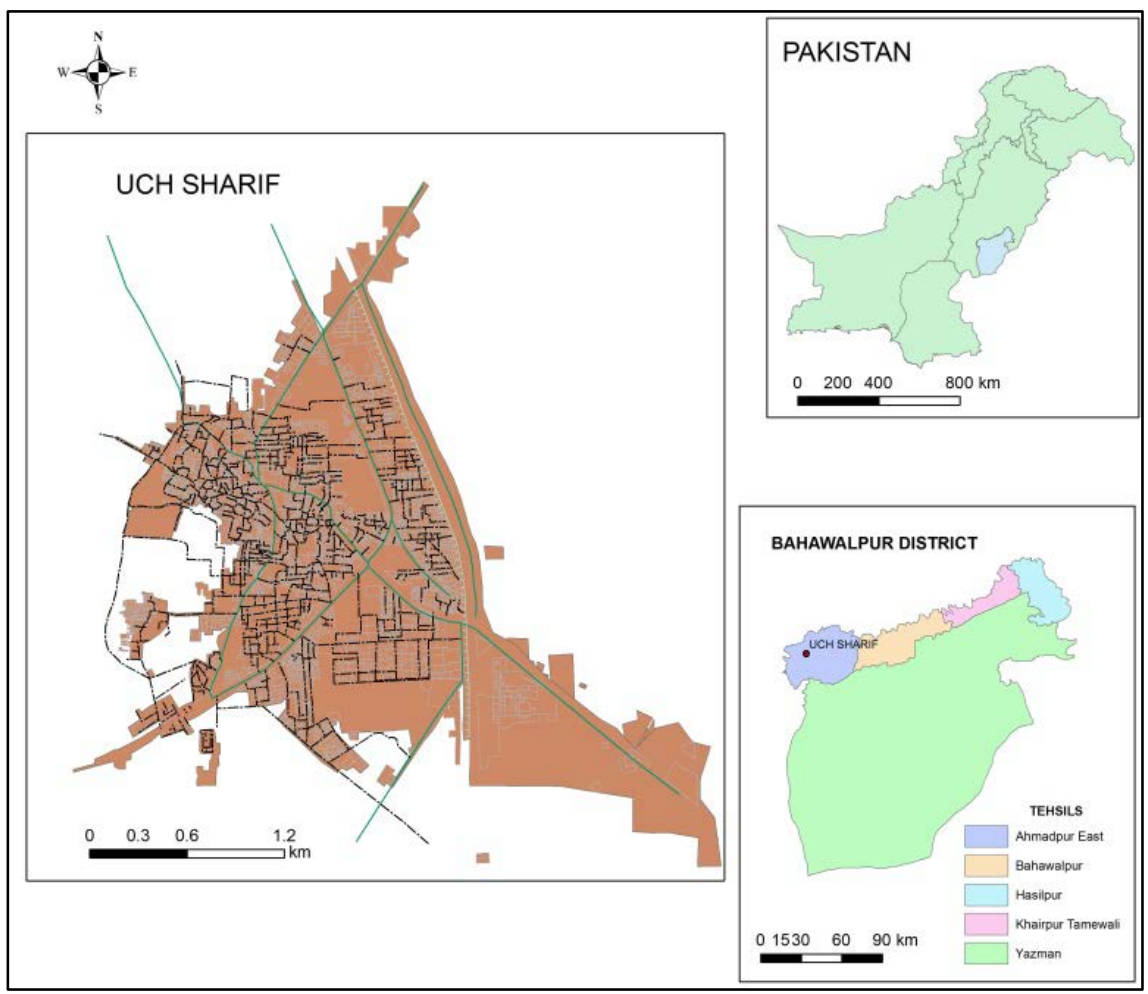

Figure 1. Location of study area "Uch Sharif" in Bahawalpur District of Pakistan 
Table 1. List of data and material used in study

\begin{tabular}{|c|c|c|c|}
\hline Data & year & Source \\
\hline Base map of Uch city & 1973 & Town committee Uch Sharif & CDSP \\
\hline Land use map Uch city & 1983 & 1998 & Regional physical planning Department Bahawalpur map of 1973 \\
\hline $\begin{array}{c}\text { Outline Development plan } \\
\text { Of Uch city from 1998-2020 }\end{array}$ & 2016 & $\begin{array}{c}\text { Google Earth, Housing and Town planning Department } \\
\text { Bahawalpur }\end{array}$ & Land use map of 2016 \\
\hline Aerial photograph and land use map of uch & 1971 & District Census report Bahawalpur, 1971 \\
\hline Total population of Uch city & 1981 & District Census report Bahawalpur, 1981 \\
\hline Total population of Uch city & 1998 & District Census report Bahawalpur, 1998 \\
\hline Total population of Uch city & 2016 & Projected using exponential growth formula \\
\hline Total population of Uch city & & \\
\hline
\end{tabular}

The four land use maps of Uch Sahrif are prepared using different types of base maps and were put in ArcGIS 10.4 for further processing. Geo-referencing of the maps were done using GCPs from respective years aerial photographs and digitized to generate separate land use layers of Residential, commercial, educational, Religious, graveyards, and public buildings. Finally area of each land use is calculated in acres by applying UTM projection with 42 North zone number in GIS environment and used to calculate total and annual urban expansion rates in respective years using relationship (1) where $U A i+n$ and UAi are the urban area in acres at time $\mathrm{i}+\mathrm{n}$ and $\mathrm{i}$, respectively, and $\mathrm{n}$ is the interval of calculating period (in years).

$$
\mathrm{UE}=\frac{\mathrm{UA}(\mathrm{i}+\mathrm{n})-\mathrm{UAi}}{\mathrm{n} \times \mathrm{UAi}} \times 100
$$

Land consumption rate (LCR) is also used as an index to evaluate the progressive spatial expansion of the study area determined using the relationship (2). [19]

$$
\mathrm{LRC}=\frac{\mathrm{UA}}{\mathrm{P}}
$$

To analyze the urban growth of any city calculating annual population growth rate is also of similar importance as annual urban growth rate, therefore it is also calculated using the relationship (3), where $U P i+n$ and UPi are the urban population at time $\mathrm{i}+\mathrm{n}$ and $\mathrm{i}$, respectively, and $\mathrm{n}$ is the interval of calculating period (in years).

$$
\mathrm{PGR}=\frac{\mathrm{UP}(\mathrm{i}+\mathrm{n})-\mathrm{UPi}}{\mathrm{n} \times \mathrm{UPi}} \times 100
$$

\section{Results}

Results of the current study are divided in two parts

1. Spatial growth of the city in terms of increasing and changing land use pattern

2. Population growth and rate of urban expansion in Uch Sharif

\subsection{Spatial Growth of the City in Terms of Increasing and Changing Land Use Pattern}

Uch Sharif is an ancient and historical city inhabited since 2000 years ago. It is expanding towards eastern, southern and northern sides from last several years. Temporal and spatial growth of Uch Sharif is clearly showing its significance as a growing urbanized city. Two hundred years ago, the length and width of Uch Sharif was 36 mile towards east and west and 34 mile towards south and north. The capital place of the city was Uch Bukhari. Spatial growth of the city is studied by analyzing temporal increase and change in land use pattern of the city as described below.

\subsubsection{Land Use of Uch in 1973}

Historically significant urban growth of Uch city starts after year 1970 when flood destroyed the city completely and its land use became confined to a very little area. After 1971, whole city was rebuilt by descendants of Pir Jalalud Din and Pir Jillani in the main quarter of "Uch Bukhair" to maintain its historical and religious importance. Even than land use pattern of Uch Sharif in 1973 was not very much expanded and limited to only 157 acres. City was divided into two major residential portions namely; Uch Bukhari in the north and Uch Gillani in the south. Majority population of the town resided in Uch Bukhari including many noble families like "Jalal ud Din (R.A)". Below Uch Bukhari, population was confined to two small mohallas named Khawajgan and Sodhgan. Uch Gillani was present in the south of the town. Residential share of Uch in 1973 was 112 acres making 71\% of the total area. Commercial area of the town was confined to only one retail market running along the Uch Bukhari and Uch Gillani and named as "traditional Chunnri Bazar" of Uch. Area occupied by this retail market was 12 acres. According to town municipal committee total number of houses in 1973 was not more than 882. Public facilities were also limited in number and with only three educational institutes, one Government hospital, Post office in Mohalla Gillani and Municipal town committee occupying the total area of 10 acres. Educational institutes occupied 8 acres. Religious area included tombs and historical graveyards and constituted 13 acres from the total 157 acres. At that time, no industrial development occurred and industrial area was limited to half acres only shared by some small scale industries. Figure 2 shows the land use pattern of the Uch city in 1973 and figure 3 shows the percentage share of each land use in 1973 and clearly indicates highest proportion of 
residential area that was $71 \%$ followed by $7 \%$ and $8 \%$ share of commercial and religious areas, $5 \%$ educational and $6 \%$ shared by other public facilities. In the period of 1973 political stability was ruled by chairman and Uch was distributed into six wards and each ward was ruled by a counselor which became a positive sign of development for spatial growth of the city. However municipal facilities were not much developed and drinking water supply was also very limited. There was no underground sewerage system with only one open pakka drain system called nali. Waste collected from the open drainage was used for agricultural purposes in the peripheries of city.

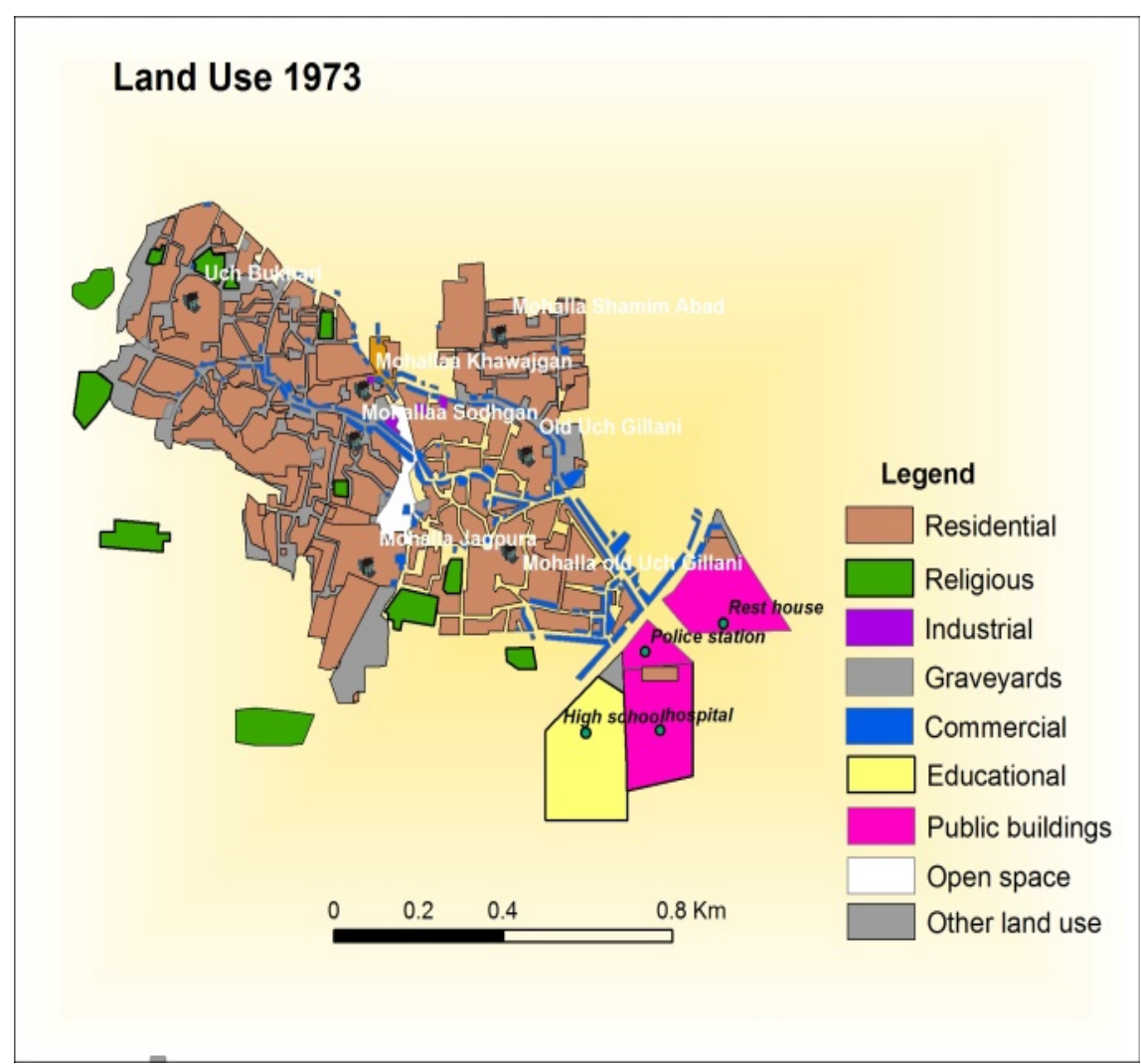

Figure 2. Land use pattern of Uch Sharif in 1973

\section{Land use1973}

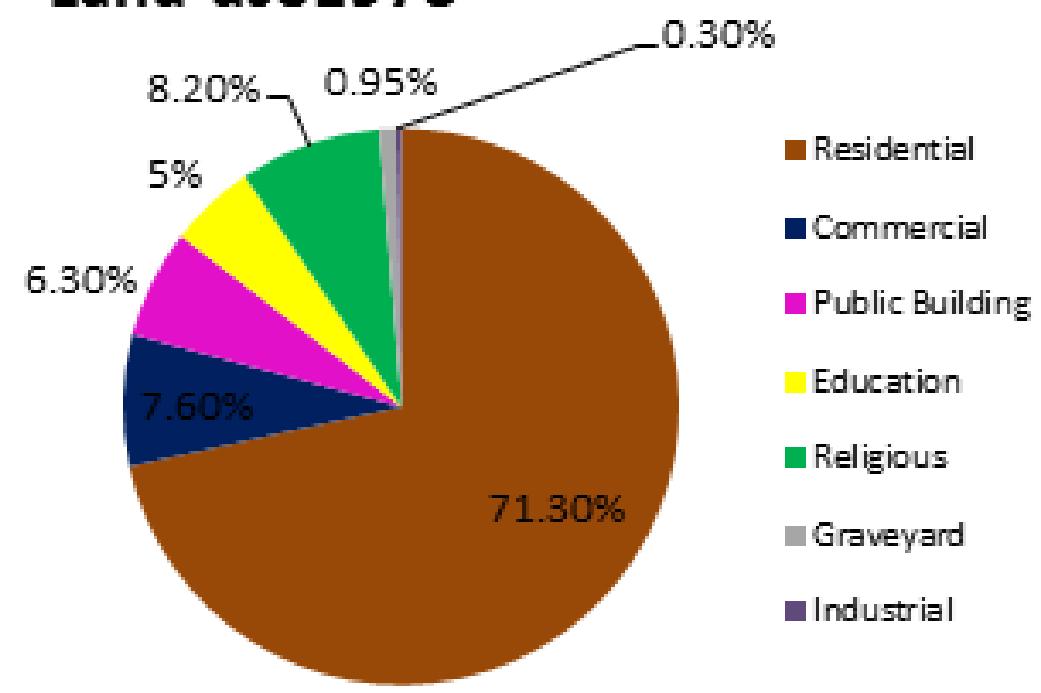

Figure 3. Proportion of different land use in 1973 


\subsubsection{Land Use of Uch in 1983}

Although no particular records of master plan were available cince 1983 to examine the spatial growth of Uch Sharif, but interview records with town committee and base maps of land use pattern shows a good diversification of land use pattern of the city in 1980. The city expanded in its total area and strong land use classes developed like residential, commercial, public buildings, educational etc. As Uch Bukhari became concentrated with residential structure, therefore movement of people in the search of new residential schemes became a major cause of city expansion in this time period

City started expanding towards Uch Gillani with the development of new residential colonies including New Uch Gillani in the south and Shams Colony in the south eastern side as shown in figure 4. Hence Residential share of this small city became 216 acres with a net increase of 104 acres. Along with the development of new residential colonies other land use also developed to provide educational, health and other public facilities for the increasing population. Commercial development in the form of presidia shops, medicine shops, cement and sanitary stores, fertilizers shops with increased area of 20 acres. Commercial expansion also lead to the development of transportation infrastructure and main " circular road" developed in the middle of city dividing it into two halves. Moreover, educational land use occupied 13 acres and public buildings occupied 25 acres from total land use of the city. As the city is famous for its religious and historical pattern from past, many tombs and shrines are present here occupying 11 acres of total land area as shown in table 2 .

Figure 4 and 5 shows the land use pattern of Uch shairf in 1983 and respective proportion of each land use category. It clearly indicates an increased residential share of $74 \%$ followed by $8 \%$ public facilities, $7 \%$ commercial land use,4.4\% educational share and $3.8 \%$ shared by religious tombs, shrines and other monuments

Table 2. Area and percentage share of each land use of Uch sharif from 1973 to 2016

\begin{tabular}{|c|c|c|c|c|c|c|c|c|}
\hline Years & 1973 & & \multicolumn{2}{|c|}{1983} & \multicolumn{2}{|c|}{1998} & \multicolumn{2}{|c|}{2016} \\
\hline $\begin{array}{c}\text { Land use } \\
\text { Categories }\end{array}$ & $\begin{array}{c}\text { Area } \\
\text { (acres) }\end{array}$ & Area \% & Area (acres) & Area \% & Area (acres) & Area \% & $\begin{array}{c}\text { Area } \\
\text { (acres) }\end{array}$ & Area \% \\
\hline Residential & 112 & $71.3 \%$ & 216 & $74 \%$ & 302 & $76.4 \%$ & 564 & 78.4 \\
\hline Commercial & 12 & $7.6 \%$ & 20 & $6.8 \%$ & 28 & $7.08 \%$ & 42 & $6 \%$ \\
\hline Public Building & 10 & $6.3 \%$ & 25 & $8.6 \%$ & 27 & $6.8 \%$ & 32 & $4.4 \%$ \\
\hline Education & 8 & $5 \%$ & 13 & $4.4 \%$ & 18 & $4.5 \%$ & 50 & $7 \%$ \\
\hline Graveyard & 1.5 & $0.95 \%$ & 2 & $0.68 \%$ & 5 & $1.2 \%$ & 4 & $0.5 \%$ \\
\hline Industrial & 0.5 & $0.3 \%$ & 3 & $1.03 \%$ & 4 & $1 \%$ & 14 & $2 \%$ \\
\hline Total & 157 & & 290 & & 395 & & 719 & \\
\hline
\end{tabular}

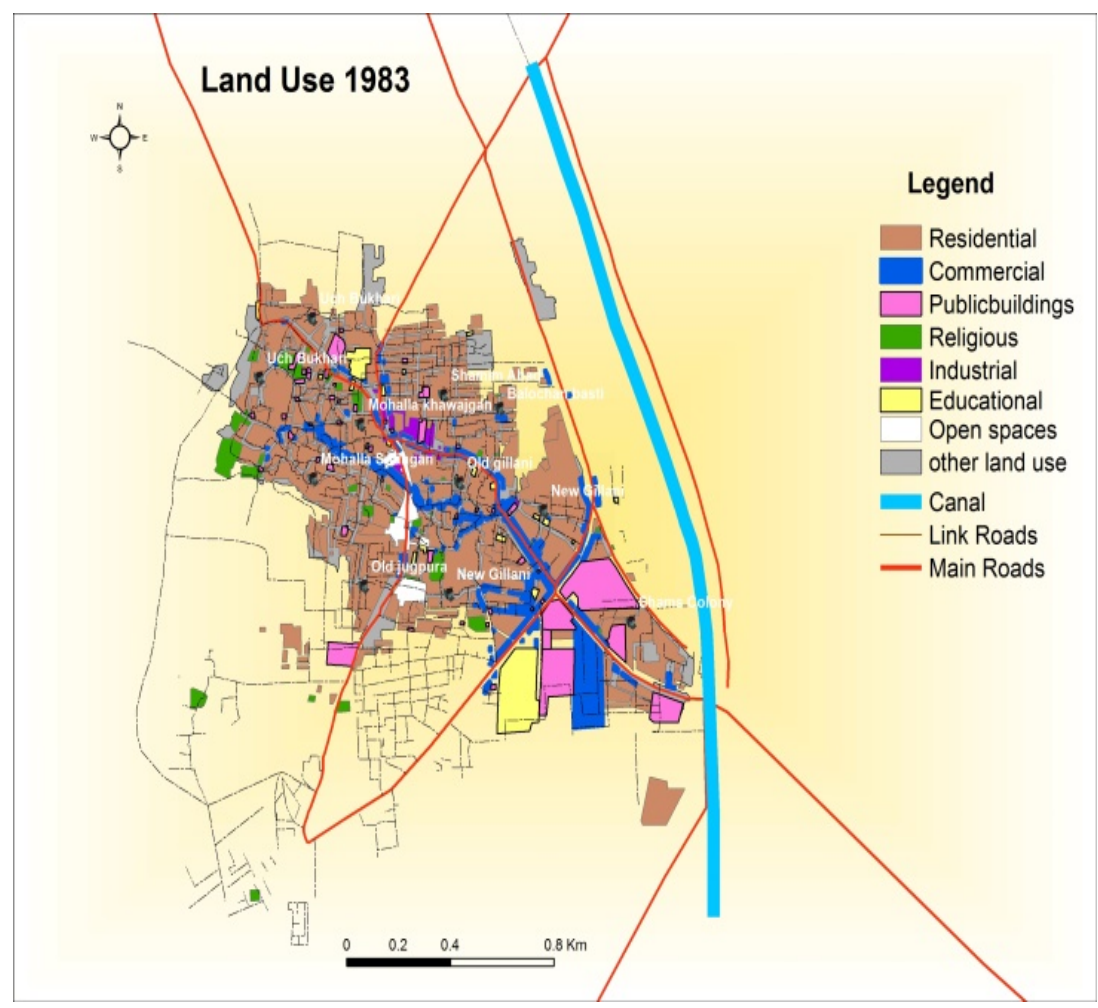

Figure 4. Land use pattern of Uch sharif in 1983 


\section{Land use 1983}

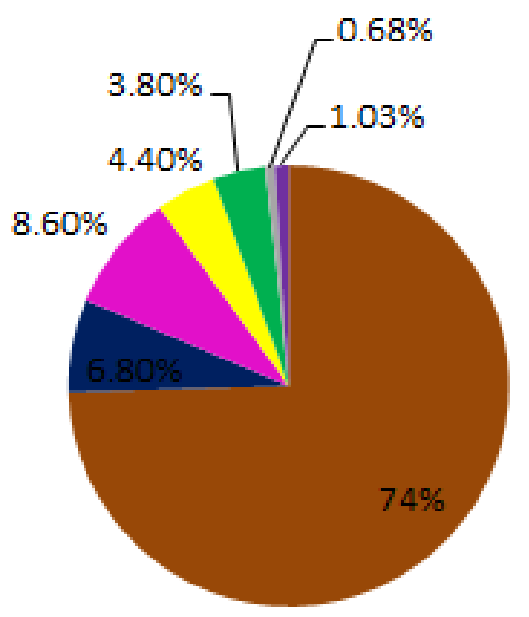

- Residential

- Commercial

- Public Building

Education

neligious

n Graveyard

- Industrial

Figure 5. Proportion of different land use in 1983

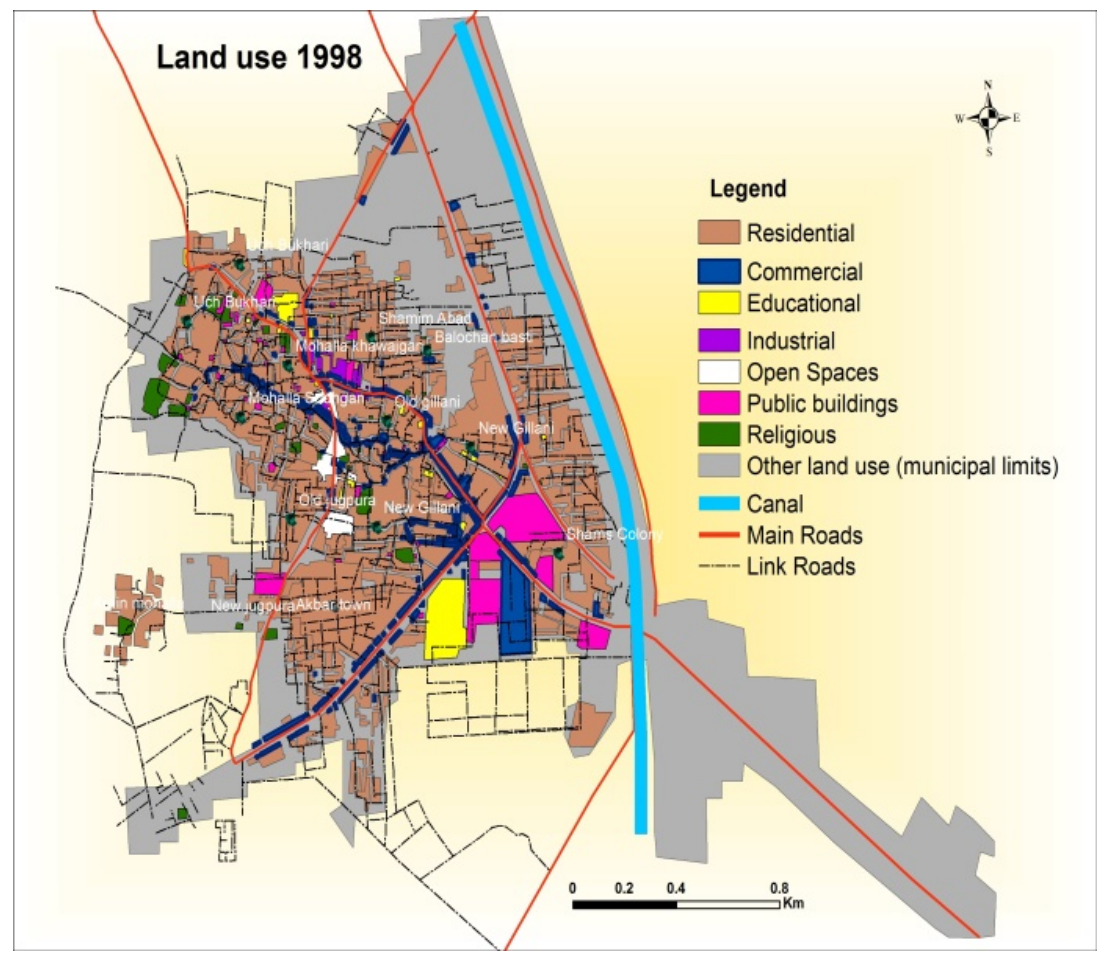

Figure 6. Land use pattern of Uch sharif in 1998 


\section{Land use 1998}

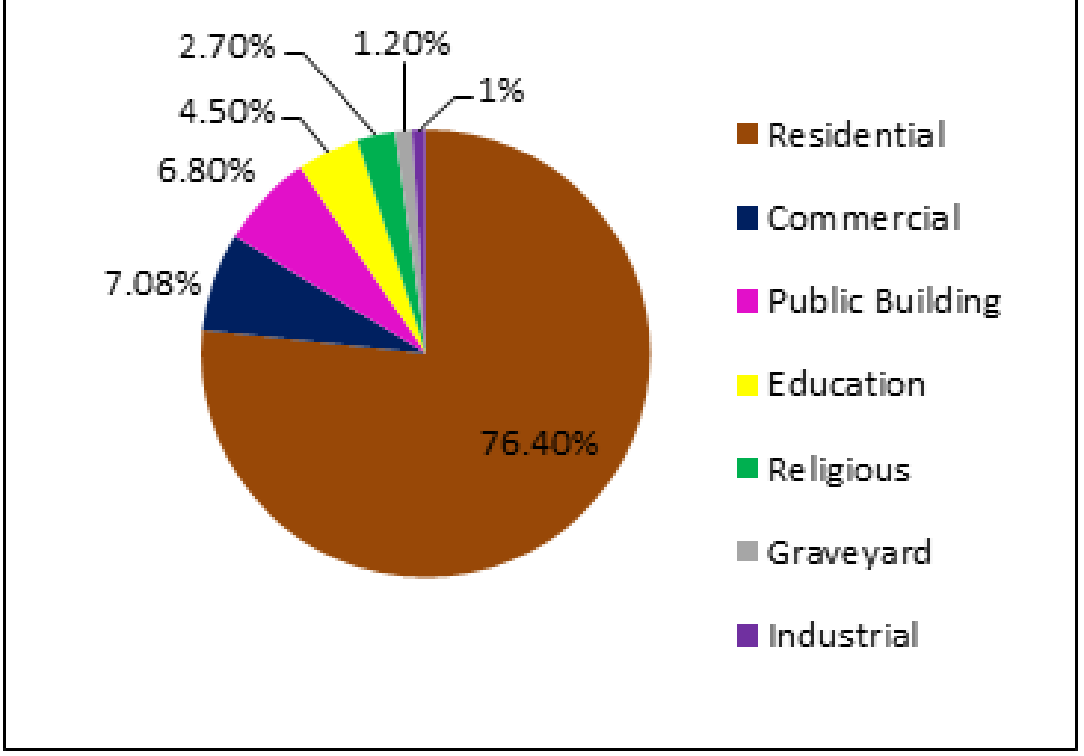

Figure 7. Proportion of different land use in 1998

\subsubsection{Land Use of Uch in 1998}

In 1998, land use of Uch Sharif became more segregated and diversified in pattern and city became reshaped into modern city structure. Population growth resulted more residential expansion and became a major reason of conversion of this town into a small city. Residential structure converted into different colonies and many new housing schemes started developing. Figure 6 shows that in 1998 a new town namely Akbar town developed in the south of the city and new Gillani also extended towards southern side. Opposite to Akbar town, two other settlements named new jagpura and Mohalla Araien also came into existence. Other than these, eastern side of the city also expanded in the form of New Shams colony which extended towards north of the city.

Other than residential, commercial sector also grew in its spatial context. Residential area occupied 302 acres making $76.4 \%$, commercial area occupied 28 acres making $7 \%$ of total area. Many small industries started developing and occupied the area of 4 acres making almost 1\% shown by figure 7 . Area occupied by educational institutes also increased and reached to 18 acres with $4.5 \%$ of the total area. Other public facilities also increased and new infrastructure was added in existing land use pattern such as telephone exchange, WAPDA office, Banks and police stations. All such public facilities occupied 27 acres sharing $6.8 \%$ of the total land use. Other than mentioned public facilities, municipal services also needed to be reestablished in this time period to fulfill the needs of growing population.

\subsubsection{Land use of Uch in 2016}

Currently Uch sharif has been organized as modern and well-structured city with diversified land use pattern. Its
Residential land use has been converted into different colonies and towns rather than Mohallas and many new housing schemes have been developed including Akbar town and Umar town on the southern side, Sami colony on the south eastern side, Ali town and Rao colony on the northern side, New Shams colony on the eastern side. The residential development has been reached to 564 acres making $78.4 \%$ of the total area. Number of houses has been currently reached to 5000 in number. Other than residential development, commercial area has been also increased along with new residential schemes making a sharp increase of 42 acres. Main traditional Bazar of the city also became concentrated with a total count of 8000 shops distributed along Alipur road, Khairpur daha road, and main circular road of the city. Currently "traditional old bazar" of the Uch shairf has become separated into Uch Bukhari Bazar, Gillani Bazar and Sadar Bazar. New Sadar bazar of the modern city has mixed commercial structure of retail and wholesale. Other than Residential and commercial growth of the city, industrial development is also very significant in shaping the recent land use pattern of Uch Sharif. Many new industries including cotton factory, flour and saw mills and ice factories, jinning and oil factory have increased the industrial area which has been reached to 14 acres. Furthermore, educational development is another important land use change in modern Uch with a sharp rise of 50 acres as compared to 18 acres in a1998. Figure 9 shows the complete land use pattern of the current modern Uch Sharif with municipal limits. Likewise 1998 increasing public facilities is also an important characteristics of recent year with the establishment of new hospitals to provide basic health services, new educational institutes from primary to graduate level, banks and Agricultural development organizations are 
reshaping an old town to a modern city. Recent industrial development of the city is also creating new job opportunities for the residents. Development of agricultural farmlands at the periphery areas of the city is not only fulfilling subsistence needs of growing population but also helping to make the city more commercialized in future. Figure 8 shows the percentage share of each land use in the recent year with $78 \%$ share of residential area, $6 \%$ share of commercial land use, $7 \%$ share of educational land sue, $4.4 \%$ share of public facilities and $2 \%$ share of industrial development.
After 2010, municipal services of Uch Sharif have become more established as were in the past. With increasing population growth of the city needs and demands of public facilities also raised and the city became more facilitated for basic urban services of water and sanitation. A well-developed underground sewerage system has been built by local government as compared to open drainage system in the past. Waste water disposal points are being fixed in various parts of the city to collect and dispose off the urban waste.

\section{Land use 2016}

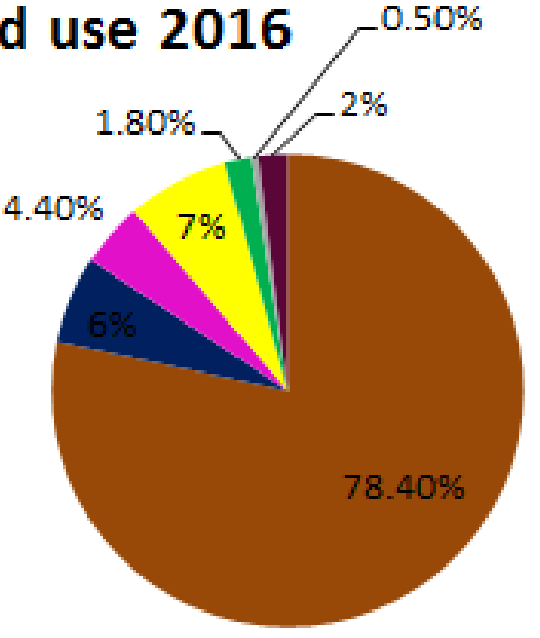

Residential

Commercial

Public Building

Education

Religious

- Graveyard

Industrial

Figure 8. Proportion of different land use in 2016

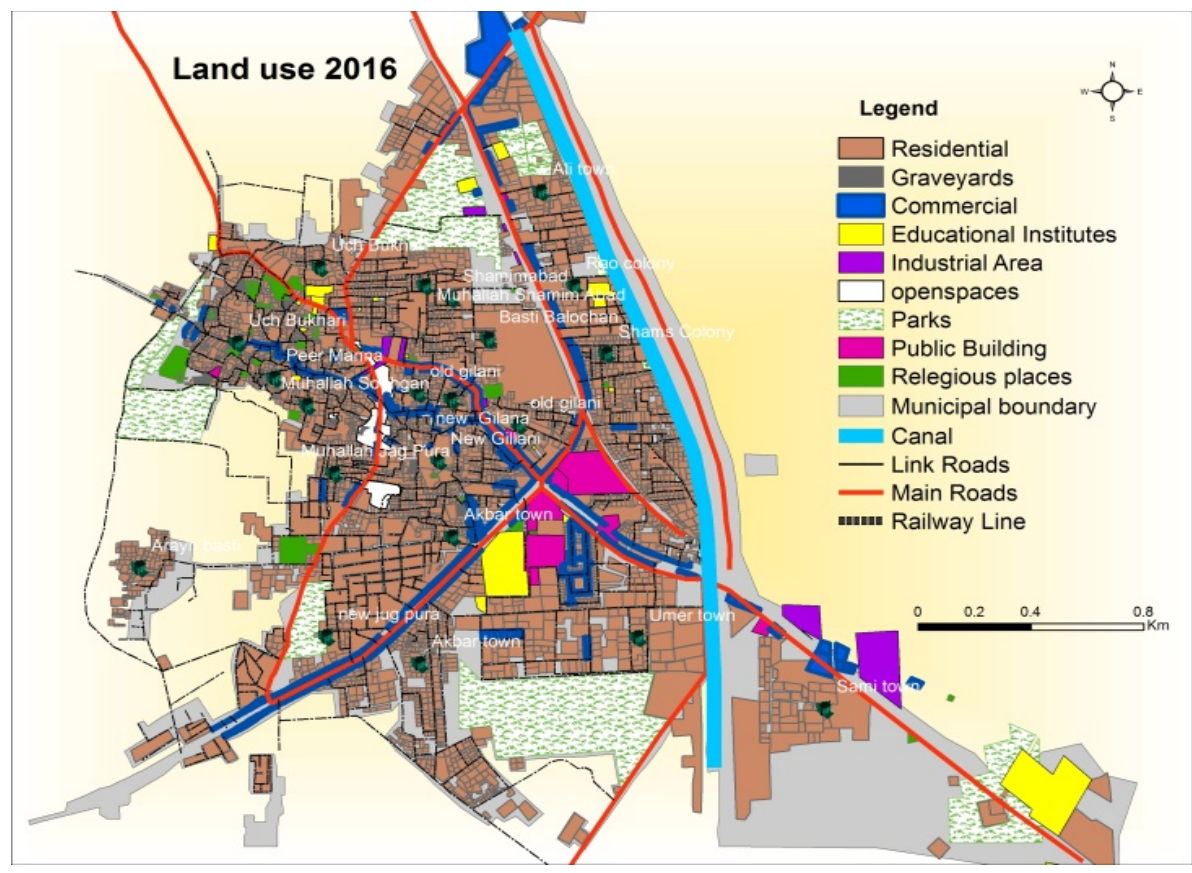

Figure 9. Land use pattern of Uch sharif in 2016 


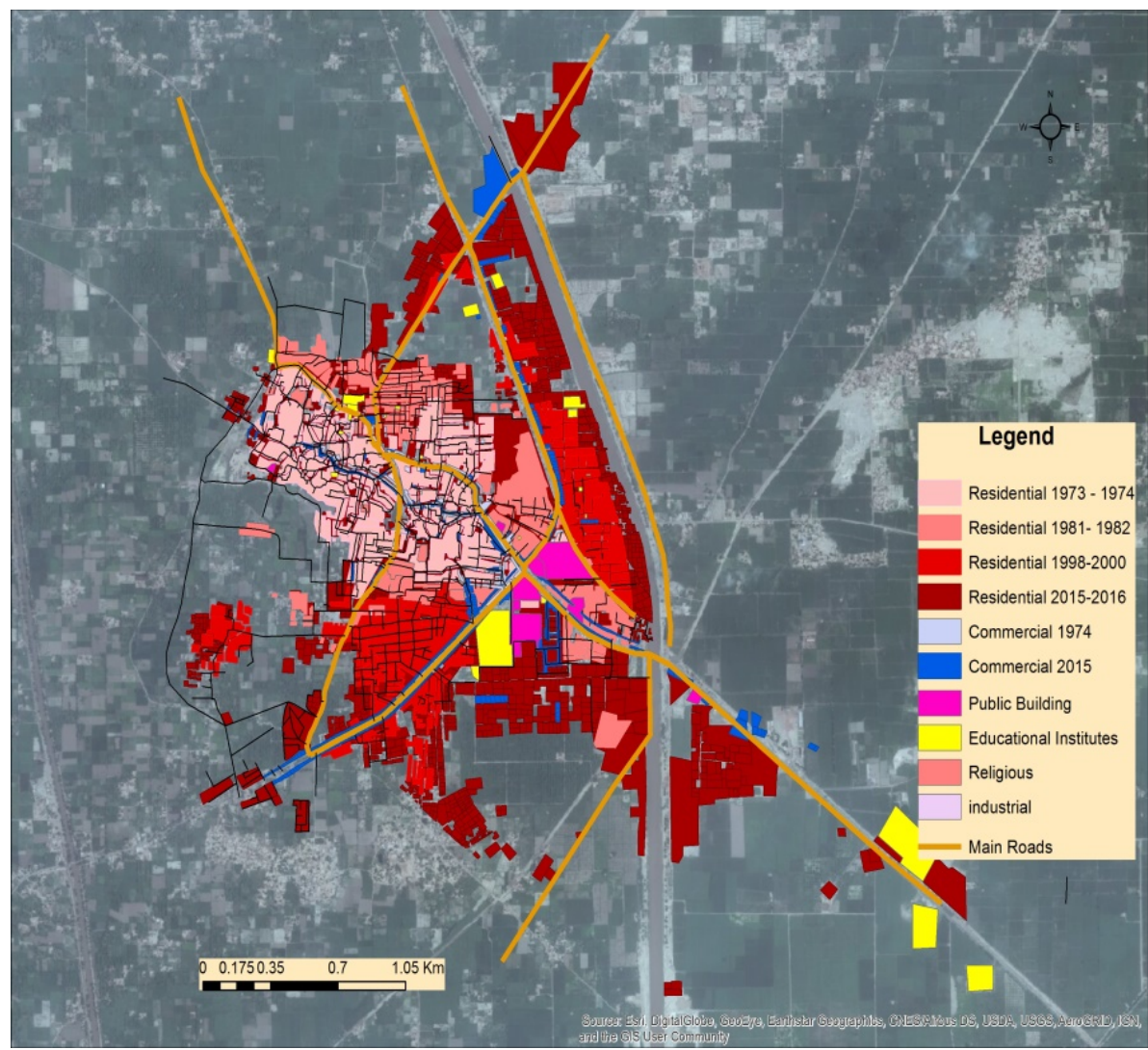

Figure 10. Residential and urban expansion of Uch Sharif from 1973 to 2016

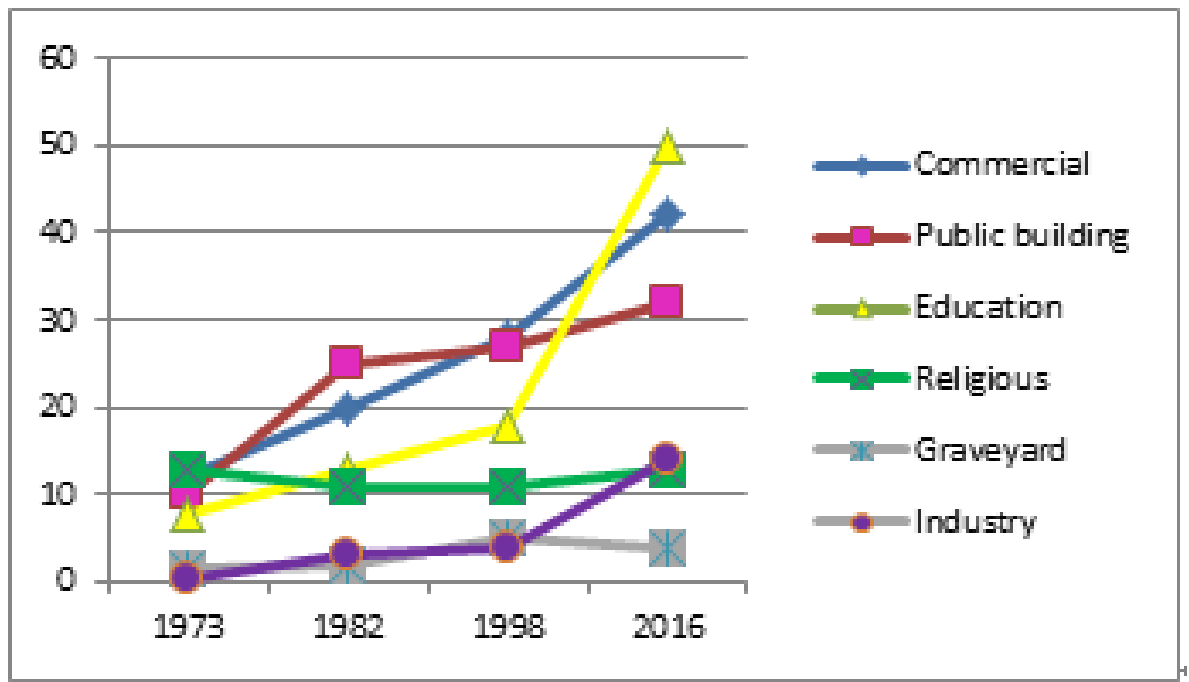

Figure 11. Urban growth by different land use other than residential

Spatial dimensions of urban and residential growth of the city are shown in figure 10 which clearly amplifies the argument of "small cities urbanization" due to residential and infrastructure development. Figure also displays that residential growth of the city took place from 112 acres in 1973 to 564 acres in 2016 with a total urban growth of 157 acres in1973 to 719 acres in 2016.

Figure 11 also indicates the change in land use pattern of other land use categories and evidently proves the urban growth of the city in the form of commercial, educational and industrial development. However, a fast and rapid increase is observed after 1998 in all sectors. There is sharp rise of educational development in the town. Development of new private schools and colleges are fulfilling the educational needs of growing population. In the same manner other public facilities also increased in every time period and sharing its part for urban development of the city. Industrial development of the cities is also an important sign of urban 
growth and city development. New industrial development at small and large scale also helped to urbanize the city in spatial extent.

\subsection{Historical Population Growth of Uch Sharif and its Rate of Urban Expansion}

According to 1971-72 census records, population of uch city in 1972 was 8,491 persons which increased to 13,386 persons in 1981with average annual growth rate of 5.5\% [20]. In 1972-73, Uch city was divided into two blocks only namely, Uch Bukhari and Uch Gillani. Most of the population resided around the tombs and shrines of Uch Bukhari and sparse population was present in Uch Gillani. In 1980, Uch Sharif divided administratively into blocks system. Uch Bukhari was further divided into seven blocks and Uch Gillani became divided into five blocks. Uch bukahri was still considered as high population density block. According to District Census Report, 1998 [17], urban population of Uch Sharif reached to 20476 persons with extended residential schemes. Old noble families started to sale their land property for agricultural purposes and migration from nearby rural union councils increased in this time period. Many agricultural farmlands started developing around the periphery of cities especially on the western side. Other than croplands many open land in the western and south western side also converted for small scale vegetable farming. In 1998, total number of houses reached to 3250 in number. Urban growth took place not only on the peripheries of city but interior city like Uch Bukhari also became more concentrated with houses and development of new public facilities which altered the land use pattern of the city. The minimum population of Uch bukhari in 1980 was 891 individuals and maximum population 3784 individuals. While in 1998, minimum population started with 1139 individuals and maximum population was 4000 individuals in Uch Bukhari. After 2013, Uch city was divided into circles and currently whole Uch is covered in three circles namely C1, C2 and C3 with merging of previous blocks into new circles. Currently, estimated population of the Uch calculated by using exponential growth model has been reached to 34,859 persons and number of houses has been reached to 4500. Recently in 2016, highest growth of the city is taking place on the south eastern side and on the northern side along with the Abbasia canal.

Urban growth of Uch Sharif can be best analyzed by calculating the total urban growth rate, annual urban growth rate, and annual population growth rate. Table 1 and table 2 shows the urban and population growth of Uch Sharif in respective time periods. A positive correlation is observed between population growth and urban growth of this small city. It is also clear for the table 1 that population density of the Uch was 54 persons per sqkm in 1973 which became 46 persons per sqkm in 1983 and again increased to 51 persons per sqkm in 1998 and according to recent estimates it is 48 persons per sqkm. Table 2 reveals the rate of urban growth in Uch Sharif in different time periods and shows that from 1973 to 1983 total urban growth of the city was $84 \%$ with annual growth rate of $8.4 \%$, while from 1983 to 1998 total urban growth of the city was $36 \%$ with annual growth rate of $2.4 \%$ which again raised to $82 \%$ from 1998 to 2016 at an annual rate of $4.5 \%$. The overall growth rate of the city in the whole time period of 43 years from 1973 to 2016 was 358\% with an annual increase of $7.2 \%$. The fluctuation in the urban growth rate and population growth rate reflects almost similar trends in different time periods. The reasons behind this variability are the historical flood of 1970 which destroyed the city and resettlement of the city started again in 1973. Noble and influential families of the city started making new homes adjacent to the tombs and also around periphery areas of the city. From 1983 to 1998 total urban change was 105 acres which was less than previous change while population change was 7000 persons which was more than previous change of 4895 persons. Thus table 2 reveals more population growth and less urban growth from 1983 to 1998. Therefore, population density in 1998 was also higher i.e. 51 persons per sq.km as compared to it was in 1983 i.e. 46 persons per sq.km. After 1998, urban and population growth of the city both increased progressively with the population change of 26,645 persons and urban change of 324 acres. Population and residential density is also higher with 48 and 62 persons per sq.km as was in 1983. The absence of structural land use plan of the city has caused haphazard residential expansion by 2016 in the three sides of the city especially on the south eastern side with most real estate developments in the search of better and cheaper land. Hence, non-productive land around the city is currently being used for new residential schemes. Such kind of land use expansion increases the municipal limits of the city and causes its urban growth but on the other hand also decreases the population density due to random population distribution.

Table 3. Urban and population growth of Uch Sharif from 1973 to 2016

\begin{tabular}{|c|c|c|c|c|}
\hline & 1973 & 1983 & 1998 & 2016 \\
\hline Total urban Area & 157 & 290 & 395 & 719 \\
\hline Population & 8,491 & 13,386 & 20,476 & 35,136 \\
\hline Population density per sq.km & 54 & 46 & 51 & 48 \\
\hline Land consumption rate & 0.01 & 0.02 & 0.01 & 0.02 \\
\hline Residential population density per sq.km & 72 & 61 & 67 & 62 \\
\hline
\end{tabular}


Table 4. Indicators of urban growth in Uch Shairf from 1973 to 2016

\begin{tabular}{|c|c|c|c|}
\hline & $1973-83$ & $1983-98$ & $1998-2016$ \\
\hline Urban change (acres) & 133 & 105 & 324 \\
\hline Population change & 4,895 & 7,090 & 14,660 \\
\hline Total urban growth rate & $84.7 \%$ & $36 \%$ & $82 \%$ \\
\hline Annual urban growth rate & $8.4 \%$ & $2.4 \%$ & $4.5 \%$ \\
\hline Population growth rate & $5.7 \%$ & $3.5 \%$ & $4.3 \%$ \\
\hline
\end{tabular}

\section{Conclusions}

Researches on the urban growth of small cities have gained very little attention from past. But recent trends of urban growth are taking place not only in metropolitan cities but also in small cities lying near to big cities. Awareness of modern lifestyles has changed the population demands of better infrastructure and public facilities within every city. Modern designs housing schemes have attracted the people to settle in periphery areas of the cities where land would be cheaper and extended. Development in transportation infrastructure like road network and increased vehicles have also increased the accessibility towards the city centers. Such reasons are causing changes in the land use pattern of the small cities of developing countries. Uch is also included in small cities of Province Puanjb in Pakistan and has witnessed rapid urban growth in term of city expansion and population growth. The sake of better civic facilities motivated the influential families of Uch to sale their land for agricultural purposes according to land acquisition act of the country. Natural growth and rural-rural and rural-urban migration also fostered in the reclassification of Uch town into city in 1981. Rate of urban and population growth in the current research is a clear evidence of urban expansion of this small town. Recently, the haphazard and continuous residential expansion of the city may cause serious problems of urban sprawl in the future because much foreign remittance is also being invested for the construction of modern design residential schemes like sami town in south east, ali town in the north and etc. resulting irregular urban expansion of the city. Hence there is a strong need of proper urban planning in this city and master plan of the city should be prepared with distinguished structural land use planning. This research can be beneficial for the urban developers and planners to access the trend of urban growth of Uch from past to present and can better fill the gap between planning and implementation.

\section{REFERENCES}

[1] Jadab Chandra Halder. Land Use/Land Cover and Change Detection Mapping in Binpur-II Block, Paschim Medinipur District, West Bengal: A Remote Sensing and GIS Perspective. 2013;8(5 (Mar. - Apr. 2013),):20-31.

[2] Moser S.C. A Partial Instructional Module on Global and
Regional Land Use/Cover Change: Assessing the Data and Searching for General Relationships. Geojournal 1996;39(3):241-83.

[3] Meyer W.B., Turner B.L.I., editors. Changes in Land Use and Land Cover: A Global Perspective. Cambridge: Cambridge University Press; 1994.

[4] Mitra A.P., Sharma C. Global environmental changes in South Asia : a regional perspective. Dordrecht, The Netherlands; New York; New Delhi: Springer ; Capital Pub. Co.; 2010.

[5] Briassoulis H. Factors influencing Land Use and Land Cover Change. Encyclopedia of Life Support System, EOLSS2000. p. 1-9.

[6] Tisdale $H$. The Process of Urbanization. Soc F. 1941;20:311,Angel S., Sheppard S.C., Civco D.L. Dynamics of global urban expansion. Washington DC: World Bank2005,UN. World Population Prospects: 2012 Revisions. NewYork: United Nations: Department of Economic and Social Affairs, Population Division 2012,UNHABITAT. State of the World's Cities 2010/2011: Bridging the Urban Divide. : Earthscan, London/Sterling, VA2010.

[7] Ellis E. Land use and Land cover Change. In: Pontius R, editor. The Encyclopedia of Earth 2010.

[8] UN. Manuals on methods of estimating population: Methods for projections of Urban and Rural Population. New York: Department of economic and social affairs: United Nations1974.

[9] Pham H.M., Yamaguchi Y., Bui T.Q. A case study on the relation between city planning and urban growth using remote sensing and spatial metrics. Landscape and Urban Planning. 2011;100(3):223-30.

[10] Rui Y. Urban growth moodelling based on land use changes and road network expasnion. Sweden: Royal Institute of technology, Stockholm; 2013.

[11] Acharya A.K., Nangia P. Population growth and changing land use pattern in Mumbai Metropolitan region of India. Caminhos De Geograofia. 2004;11(11): 168-85.

[12] Roberts B., Kanaley T., editors. Urbanization and Sustainability in Asia: Asian Development Bank; 2006.

[13] GOP. National Report of Pakistan for HABITAT III. Islamabad: Government of Pakistan, Ministry of Climate change 2015.

[14] Aljoufie M., Zuidgeest M., Brussel M., Maarseveen M.v. Spatial temporal analysis of urban growth and transportation in Jeddah City, Saudi Arabia. Cities. 2013; 31: 57-68.

[15] Basawaraja R., Chari K.B., Mise S.R., Chetti S.B. Analysis of 
the impact of urban sprawl in altering the land-use, land-cover pattern of Raichur City, India: using geospatial technologies. Journal of Geography and Regional Planning 2011;4(8):455-62, Bhatta B., Saraswati S., Bandyopadhyay D. Urban sprawl measurement from remote sensing data. Applied Geography 2010; 30: 731-40.

[16] Xiao J., Shen Y., Ge J., Tateishi R., Tang C., Liang Y., et al. Evaluating urban expansion and land use change in Shijiazhuang, China, by using GIS and remote sensing. Landscape and urban planning. 2006;75(1): 69-80.

[17] PCO. Fifth Population and Housing Census of 1998 in District Census Report: Bahawalpur: Pakistan Census
Organization1999.

[18] Hassan A. Migration, small towns and social transformation in Pakistan. Environment and Urbanization. 2010;22(1).

[19] Haregeweyn N., Fikadub G., Tsunekawa A., Tsubo M. The dynamics of urban expansion and its impacts on land use/land cover change and small-scale farmers living near the urban fringe: A case study of Bahir Dar, Ethiopia. Landscape and Urban Planning. 2012; 106: 149-57.

[20] PCO. Fourth Pakistan and Housing Census of 1981 in District Census Report: Bahawalpur: Pakistan Census Organization1981. 